\title{
山口県の小学校区における学童保育施設の整備状況と施設水準 CONSTRUCTION TYPE AND SUPPLY LEVEL OF SCHOOLCHILD CARE FACILITIES BY ATTENDANCE UNIT OF ELEMENTARY SCHOOL IN YAMAGUCHI PREFECTURE
}

\author{
中園眞人*1, 三島幸子*2, 細田智久*3
}

\section{Mahito NAKAZONO, Sachiko MISHIMA and Tomohisa HOSODA}

\begin{abstract}
The purpose of this study is to clarify the construction type and supply level of schoolchild care facilities by attendance unit of elementary school in Yamaguchi prefecture, and to consider the supply method of schoolchild care facility for the future. Each school attendance unit in 2010 was classified into four types : urban, plain, middle, mountainous. Although one or more schoolchild care facilities has been established in a school attendance unit by three types except for Mountainous type, there are not less than $50 \%$ school attendance units without a facility in mountainous type.
\end{abstract}

Keywords: Schoolchild Care Facility, Registry number of Pupils, Facility Supply, Yamaguchi Prefecture 学童保育施設, 登録览童数, 施設整備, 山口県

\section{1. 序論}

共働き世帯の増加等の世帯の就労形態の変化と、核家族化や 1 人 親世帯の増加等の世帯構造の変化により、小学校低学年の児童に放 課後の保育サービスや遊びの場を提供する学童保育への社会的ニー ズは高まっており、学童保育施設の量的・質的拡充が望まれている。 こうした需要の高まりにより、1950 年代に父母会等の運営により始 まった学童保育は、1997 年に児童福祉法に位置づけられ制度化され、 以後小学校内を中心に急速に施設整備が進められ、2014 年時点で全 国に約 2 万 2,000 施設が開設され一定の成果をあげている ${ }^{1)}$ 。しか し、全国学童保育連絡協議会によると潜在的な待機児童数は約 40 万人注 1) と推計されており、需要の増加に対して施設整備が追いつ かず、量的拡充のため施設定員を増やすまたは定員を定めないこと により対応する自治体も多く、大都市地域を中心に施設の大規模化・ 過密化が深刻な問題として指摘されてきた。

この課題に対応するため、2007 年に学童保育施設の設置・運営基 準を示したガイドライン注 2) が策定されたが、法的拘束力のない推 奨基準を示寸に止まり、学童保育施設の質的拡充一の対応は遅れて いた。しかし、2014 年の児童福祉法改正により 2015 年 4 月から学 童保育施設の対象児童学年が 6 年生まで引上げられ、施設定員や 1 人当り専用区画面積がガイドラインの推奨值から設置基準注 3) とし て明示されたことより、施設の大規模化・過密化には一定の歯止めが かかり質的拡充につながるものと期待される。こうした課題が指摘 される地域がある一方、児童数が少ない過疎地域を中心に施設整備 そのものが進まない空白地域も存在し、国民生活センターの調查報 告注 4) では「必要とする子どもが利用できるように学童保育サービス
の空白自治体を解消すること」が課題として指摘されている。学童保 育施設の整備状況の地域間格差は大きく、大都市地域等では施設不 足の解消々適正規模確保が主要課題であり、地方圏の都市の場合も 設置基準確保のための施設拡充が課題である。一方地方圈の農山漁 村地域では少子化が継続し、校区内の児童数減少に伴い学童保育の 運用自体が困難な地域も多く、未整備校区の解消が課題といえる。

学童保育施設の整備状況に関する既往研究には、全国のアンケー 卜調查 (235 施設)をもとに、基盤条件 (運営主体・施設形態·開所場 所）と活動実施状況の関連分析を行い、条件毎に保育環境整備の課題 を整理した研究 ${ }^{1)}$ 、全自治体へのアンケート調查(1031 自治体)をも とに、人口規模による整備状況の差異の実態や大規模施設の分割等 による対応状況、ガイドライン策定が自治体指針作成に及ぼした効 果を示した研究 ${ }^{2)}$ 等がある。筆者らは中国四国地方全域を対象に、 旧自治体単位の地域分類と施設設置形態との関連分析を行い、都市 と過疎農山村地域における設置形態の相違性と施設整備率及び施設 水淮の地域格差の存在を指摘した ${ }^{3,4)}$ 。また宇部・松江市の先進的取 組みを対象に、施設の設立経緯と校区毎の施設整備方式を整理し、 利用児童数増加に対応した施設拡充の状況に関し報告した ${ }^{5)}$ 。但し 筆者の管見によれば、地域施設配置計画論の観点からの学童保育施 設に関する研究蓄積は全体的に少ないのが現状である。

施設の空間計画に関しては、施設職員への聞取り, 平面・家具配置 実測, 観察調查をもとに、活動内容・活動機能と平面構成の対応に関 し、2 室 2 領域と 2 室 3 領域の空間構成モデルを提示した研究 ${ }^{6)}$ 、 コーナーを有す 1 室型施設を対象に、座った行為 (4 種類) と動く行 為 (5 種類) の場所 ( 7 区分) の分析から、個人別に行為の種類・遊びの
*1 山口大学 名誉教授. 工博

*2 島根大学学術研究院環境システム科学系 助教・博士 (工学)

*3 島根大学学術研究院環境システム科学系 教授・博士 (工学)
Emeritus Prof., Yamaguchi Univ., Dr.Eng.

Assist. Prof., Institute of Envi. Systems Science, Academic Assembly, Shimane Univ. Dr.Eng.

Prof., Institute of Envi. Systems Science, Academic Assembly, Shimane Univ., Dr.Eng. 
Table1 Number of elementary schools, schoolers and school child care facilities by prefecture in Chugoku region (2015)

\begin{tabular}{c|r|r|r|r|r|r}
\hline & $\begin{array}{c}\text { Municipalit } \\
\text {-ies in } \\
2015 \\
\text { 自治体数 }\end{array}$ & $\begin{array}{c}\text { Municipalit } \\
\text {-ies in } \\
2000 \\
\text { 自治体数 }\end{array}$ & $\begin{array}{c}\text { Population } \\
\text { 人口 }\end{array}$ & $\begin{array}{c}\text { Elementary } \\
\text { schools } \\
\text { 小学校数 }\end{array}$ & $\begin{array}{l}\text { Facilities } \\
\text { 施設数 }\end{array}$ & $\begin{array}{c}\text { Pupils } \\
\text { 児童数 }\end{array}$ \\
\hline Hiroshima & 23 & 86 & $2,843,990$ & 508 & 619 & 152,704 \\
\hline Okayama & 27 & 78 & $1,921,525$ & 410 & 490 & 103,081 \\
\hline Yamaguchi & 19 & 56 & $1,404,729$ & 320 & 386 & 70,045 \\
\hline Simane & 19 & 59 & 694,352 & 211 & 227 & 35,426 \\
\hline Tottori & 19 & 39 & 573,441 & 135 & 155 & 30,238 \\
\hline Total & 107 & 318 & $7,438,037$ & 1,584 & 1,877 & 391,494 \\
\hline
\end{tabular}

人数の相違性と特徵を整理し、児童の過ごし方の多様性と空間構成 の関連を論じた研究 ${ }^{7)}$ 、拠点設置方法が異なる放課後子ども教室の 使われ方調查をもとに、特別教室, 別棟専用室, 2 階多目的室, 複数多 目的スペース拠点毎に長所・短所を整理し整備の要点を論じた研究 8)、民家を活用した学童保育施設を対象としたアンケート及び聞取 り調査をもとに、生活空間·玄関·設備・而震·避難等の 10 項目の必要 となる空間条件と計画課題を提示した研究 ${ }^{9)}$ 、農家の納屋改修施設 を対象に、児童数の異なる平日放課後と夏休み期間中の施設の使わ れ方調查をもとに、児童の逃げの場と職員の先行的準備始末行為の 場が確保可能な 2 室 3 領域型空間構成の有効性を指摘した研究 ${ }^{10,11}$ を始め多くの研究成果がある。また施設の規模計画に関しては、運 営主体の異なる施設を対象とした使われ方調查より学童活動と遊び の使用面積を算定し、児童の行為に要する面積をもとに専用室の必 要面積を論じた研究 ${ }^{12)}$ や、アンケート調查をもとに保育場所数、 保育室の用途区分形態と適切な人数・面積規模の関係等を検討した 研究 ${ }^{13)}$ 等があり、施設の空間構成や規模計画に関する研究成果の 蓄積が進んでいる。このように、施設の空間計画に関する研究に対 し地域施設計画に関する研究蓄積は少なく、大都市圈と地方圈、都 市と農山漁村の地域格差等に視点を置いた整備状況把握と課題整理 及び地域条件に対応した施設整備のあり方の検討が重要と考える。

本論では中国四国地方全域を対象とした学童保育施設整備状況の 広域分析 ${ }^{3,4)}$ に続き、地方自治体に対する行政指導を担い、地域政 策の独自性が反映する県を単位とした分析を行う。施設毎の利用登 録児童数のデータが入手可能であった山口県を対象に、旧自治体を 単位とした中国四国地方の地域類型の設定方法に対し、同様の地域 条件をもとにさらに小学校区単位に細区分した地域類型を行い、こ の地域類型と 2010 年時点の小学校区の学童保育施設設置率・施設設 置形態・利用登録児童数データを一元的に統合し、2007 年のガイド ライン (推奨基準)制定以降から 2014 年の設置基準制定以前の時期 における、地域類型と小学校区の学童保育運用形態の関係を明らか にする事を目的とする。加えて得られた知見をもとに施設拡充の地 域的方向性に関し考察する。尚、2014 年の設置基準制定による施設 整備効果に関しては、新たに調査を行い各自治体の整備動向の把握 と分析を行う計画であり、その結果に関しては稿を改めて報告した いと考えている。

\section{2. 中国地方における山口県の位置付け}

本論では山口県を対象とするが、その位置付けに関し先ず中国地 方 5 県注 5 ) の地域概要と小学校数, 児童数, 学童保育施設数 (2015 年) を表 1 に示寸。人口は広島県 (284 万人)が最も多く、岡山県 (192 万
Table2 Facilities management types in each school area by prefecture in Chugoku region (Re-insertion)

\begin{tabular}{|c|c|c|c|c|c|c|c|}
\hline \multicolumn{2}{|c|}{ Establishment type } & Tottori & Shimane & Okayama & Hiroshima & Yamaguchi & Chugoku \\
\hline \multirow{2}{*}{ S type } & $\begin{array}{l}\text { s single type } \\
\text { s単一型 }\end{array}$ & $\begin{array}{c}61 \\
(43.0)\end{array}$ & $\begin{array}{c}57 \\
(22.8) \\
\end{array}$ & $\begin{array}{c}198 \\
(46.8)\end{array}$ & $\begin{array}{c}255 \\
(45.1)\end{array}$ & $\begin{array}{c}122 \\
(35.5)\end{array}$ & $\begin{array}{c}693 \\
(40.2)\end{array}$ \\
\hline & $\begin{array}{l}\text { s plural type } \\
\text { s複数型 }\end{array}$ & $\begin{array}{c}3 \\
(2.1)\end{array}$ & $\begin{array}{c}6 \\
(2.4) \\
\end{array}$ & $\begin{array}{c}21 \\
(5.0)\end{array}$ & $\begin{array}{c}50 \\
(8.8) \\
\end{array}$ & $\begin{array}{c}30 \\
(8.7)\end{array}$ & $\begin{array}{l}110 \\
(6.4) \\
\end{array}$ \\
\hline \multirow{2}{*}{ O type } & $\begin{array}{c}\text { o single type } \\
\text { o単一型 }\end{array}$ & $\begin{array}{c}42 \\
(29.6) \\
\end{array}$ & $\begin{array}{c}71 \\
(28.4)\end{array}$ & $\begin{array}{c}87 \\
(20.6) \\
\end{array}$ & $\begin{array}{c}104 \\
(18.4)\end{array}$ & $\begin{array}{c}64 \\
(18.6) \\
\end{array}$ & $\begin{array}{c}368 \\
(21.3)\end{array}$ \\
\hline & $\begin{array}{l}\text { o plural type } \\
\text { o複数型 }\end{array}$ & $\begin{array}{c}6 \\
(4.2) \\
\end{array}$ & $\begin{array}{c}9 \\
(3.6)\end{array}$ & $\begin{array}{c}6 \\
(1.4) \\
\end{array}$ & $\begin{array}{c}9 \\
(1.6)\end{array}$ & $\begin{array}{c}14 \\
(4.1)\end{array}$ & $\begin{array}{c}44 \\
(2.6)\end{array}$ \\
\hline \multirow{2}{*}{$\begin{array}{l}S+O \\
\text { type }\end{array}$} & $\begin{array}{c}\text { so } 2 \text { facilities } \\
\text { type } \\
\text { so2施設型 }\end{array}$ & $\begin{array}{c}1 \\
(0.7)\end{array}$ & $\begin{array}{c}4 \\
(1.6)\end{array}$ & $\begin{array}{c}4 \\
(0.7)\end{array}$ & $\begin{array}{c}10 \\
(1.8)\end{array}$ & $\begin{array}{c}18 \\
(5.2)\end{array}$ & $\begin{array}{c}37 \\
(2.1)\end{array}$ \\
\hline & \begin{tabular}{|c|} 
so 3-4 \\
facilities type \\
so3-4施設型
\end{tabular} & $\begin{array}{c}0 \\
(0.0)\end{array}$ & $\begin{array}{c}6 \\
(2.4)\end{array}$ & $\begin{array}{c}1 \\
(0.2)\end{array}$ & $\begin{array}{c}2 \\
(0.4)\end{array}$ & $\begin{array}{c}6 \\
(1.7)\end{array}$ & $\begin{array}{c}15 \\
(0.9)\end{array}$ \\
\hline \multicolumn{2}{|r|}{$\mathrm{N}$ type } & $\begin{array}{c}29 \\
(20.4) \\
\end{array}$ & $\begin{array}{c}97 \\
(38.8) \\
\end{array}$ & $\begin{array}{c}107 \\
(25.3)\end{array}$ & $\begin{array}{c}135 \\
(23.9)\end{array}$ & $\begin{array}{c}90 \\
(26.2)\end{array}$ & $\begin{array}{c}458 \\
(26.6) \\
\end{array}$ \\
\hline \multicolumn{2}{|c|}{ Share type } & 9 & 20 & 17 & 13 & 0 & 59 \\
\hline
\end{tabular}

Index) s single type: One facility on the elementary school site/小学校敷地内に 1 施設開設 s plural type: Plural facilities on the elementary school site/小学校敷地内に複数開設

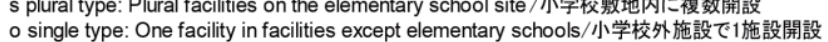
o single type: One facility in facilities except elementary schools/小学校外施設で1施設開設
o plural type: Plural facilities in facilities except elementary schools/小学校外施設で複数開設 so 2 facilities type: 2 facilities on the elementary school site and in other facilities 小学校、他施設を使用し、1施設ずつ開設

so 3-4 facilities type: $3-4$ facilities on the elementary school site and in other facilities 小学校、他施設を使用し、3-4施設開設

N type: No facilities/学童保育が開設していない

Share type: Facilities that target multiple elementary school districts 複数の校区を対象とした施設の対象となる校区

Note) Composition ratio excludes "Share type"./ 各県別の構成比は「Share型」を除外。

人)・山口県 (140 万人) がこれに次ぐ規模を有すが、島根県 (69 万人), 鳥取県 (57 万人) では 70 万人を下回り人口減少が進んでいる。小学 校数・览童数も各県の人口規模を反映し同様の傾向を示し、2015 年 時点の学童保育施設数は広島県 619、岡山県 490 施設で、政令指定 都市を有し瀬戸内海に面す 2 県の施設数が多い。逆に鳥取県 155 、 島根県 227 施設と日本海側の人口・児童数の少ない 2 県で施設数が少 なく、山口県は 386 施設で中間的值を示す。2015 年時点では全県で 施設数が小学校数を上回るまで増加してはいるが、未だに学童保育 施設が未整備な校区も多い(表 2 参照)。

次に、自治体の施設運営方針や校区の立地状況等により施設の形 態や数には相違があるため、校区の学童保育施設の設置型を学校内 に設置される S 型（校舎内或いは校庭にプレハブ等の建物を設ける 場合を含む)、学校とその他の施設に各 1 施設設置される $S+O$ 型、 その他の施設に 1 施設設置される $\mathrm{O}$ 型、校区内に施設が未整備の N 型、校区を限定しない利用を対象とした Share 型に 5 分類し、これ に加え校区内に開設されるその他の施設数を反映した 3 型 $(\mathrm{O}$ 複数 型,SO2 型, SO3 4 型) に区分し、計 8 分類に細区分した ${ }^{3)}$ 。

施設設置型の県別集計結果 (2012 年)を表 2 に示す。学校内に 1 施 設を設置する S 単一型が 693 校区 $(40.2 \%)$ と最も多いが、島根県で はO 単一型校区が 71 校区 $(28.4 \%)$ と最も多く、N型も 97 校区 $(38.8 \%) 、$ 校区をまたぐShare 型も 20 施設と多い。鳥取県ではS 型が 64 校区 (45. 1\%) と最も多いが、同時に O 型も 48 校区 (33.8\%) あり、5 県中 で O 型の割合が最も高い一方、施設未整備の N 型は $20.4 \%$ と低い。 岡山県と広島県の設置型の構成比は類似しており、政令指定都市を 有すものの中国山地の中山間地域を抱えるため、25\%前後の校区が施 設未整備の N 型である。山口県はO 型が $20 \%$ 前後で岡山県と広島県 に近い值を示すが、 $S$ 型の構成比は岡山・広島県よりも小さく、 $S+O$ 型が占める割合が高いのが特徵で、設置型の構成比には県別の差異 が存在する。

これより 2012 年時点の山口県の特徴として、第一に人口, 小学校 
Table3 Category scores of Quantification theory analysis

\begin{tabular}{|c|c|c|c|c|c|}
\hline \multicolumn{3}{|c|}{ Category/カテゴリー } & \multirow[b]{2}{*}{$\begin{array}{l}\text { School } \\
\text { district } \\
\text { 校区数 }\end{array}$} & \multirow[b]{2}{*}{$\begin{array}{c}\text { First } \\
\text { axis } \\
\text { 第1軸 }\end{array}$} & \multirow[b]{2}{*}{$\begin{array}{l}\text { Second } \\
\text { axis } \\
\text { 第2軸 }\end{array}$} \\
\hline $\begin{array}{c}\text { Regional } \\
\text { condition } \\
\text { 地域条件指標 }\end{array}$ & $\begin{array}{c}\text { Score } \\
\text { sign } \\
\text { スコア記号 }\end{array}$ & $\begin{array}{l}\text { Category pattern } \\
\text { カテゴリー分類 }\end{array}$ & & & \\
\hline \multirow{4}{*}{$\begin{array}{c}\text { Agricultural } \\
\text { classification } \\
\text { 農業区分類型 }\end{array}$} & 11 & Urban regions/都市的 & 144 & -1.12 & 0.47 \\
\hline & 12 & $\begin{array}{c}\text { Plain agricultural regions } \\
\text { 平地農業 }\end{array}$ & 15 & 0.05 & -2.16 \\
\hline & 13 & $\begin{array}{l}\text { Middle agricultural } \\
\text { regions/中間農業 }\end{array}$ & 120 & 0.77 & -0.93 \\
\hline & 14 & \begin{tabular}{|c|}
$\begin{array}{c}\text { Mountainous agricultural } \\
\text { regions/山間農業 }\end{array}$ \\
\end{tabular} & 42 & 1.61 & 1.81 \\
\hline \multirow{4}{*}{$\begin{array}{c}\text { Pupil } \\
\text { maintenance } \\
\text { rate }(\%) \\
\text { 児童維持率 }\end{array}$} & 21 & Over 83.0 & 84 & -0.78 & 0.22 \\
\hline & 22 & $66.0-82.9$ & 88 & -0.54 & -0.64 \\
\hline & 23 & $50.0-65.9$ & 69 & 0.08 & -0.24 \\
\hline & 24 & $0.0-49.9$ & 80 & 1.36 & 0.69 \\
\hline \multirow{4}{*}{$\begin{array}{c}\text { Number of } \\
\text { target pupils } \\
\text { (people) } \\
\text { 対象児童数 }\end{array}$} & 31 & Over 121 & 80 & -1.38 & 0.88 \\
\hline & 32 & $40-120$ & 93 & -0.49 & -0.90 \\
\hline & 33 & 16-39 & 64 & 0.85 & -0.74 \\
\hline & 34 & $0-15$ & 84 & 1.20 & 0.72 \\
\hline \multirow{4}{*}{$\begin{array}{c}\text { school district } \\
\text { area }\left(\mathrm{km}^{2}\right) \\
\text { 校区面積 }\end{array}$} & 41 & $0.4-5.3$ & 78 & -0.98 & 1.20 \\
\hline & 42 & $5.4-11.0$ & 81 & -0.46 & -0.39 \\
\hline & 43 & $11.1-21.6$ & 81 & 0.08 & -1.43 \\
\hline & 44 & Over 21.7 & 81 & 1.33 & 0.67 \\
\hline \multirow{4}{*}{$\begin{array}{c}\text { Pupil density } \\
\text { (people/km²) } \\
\text { 児童密度 }\end{array}$} & 51 & Over 52.0 & 83 & -1.47 & 1.46 \\
\hline & 52 & $10.0-51.9$ & 83 & -0.61 & -1.40 \\
\hline & 53 & $2.0-9.9$ & 82 & 0.67 & -1.34 \\
\hline & 54 & $0.0-1.9$ & 73 & 1.61 & 1.44 \\
\hline
\end{tabular}

数, 児童数, 学童保育施設数に関しては、中国地方 5 県の中では中間 的位置にある事、第二に小学校区内の施設設置形態に関しては、S, O 複数型、 $\mathrm{S}+\mathrm{O}$ 型の 1 小学校区に複数の施設が整備されている割合 が高く、複数の小学校が共同利用する Share 型がない事が挙げられ、 総体的に学童保育実施校区における整備水準の高い県として位置付 けられる。

\section{3. 調査概要}

以下の関連資料を収集した。(1)放課後児童クラブ一覧 (2012 年) 注 6)、(2)2000 年, 2010 年市町村区分注 7)、(3)旧自治体別共衝き世帯数 (2010 年) 注 8$)$ 、(4)旧自治体 (1950 年) 別農業地域類型注 9) (5)山口県内 各小学校の学年別巟童数 (1995, 2010 年) 注 ${ }^{10)}$ 、(6)山口県内各施設別 学童保育施設登録児童数 (2010 年)、(7)山口県小学校区図。この他学 童保育未実施自治体へのアンケート調查 (2014 年 7～9 月:62 校区)、 校区内に S 型施設がなく $\mathrm{O}$ 型施設を設置する山間地域自治体の聞 取り調查 (2014 年 8〜11月:16 自治体)を実施した注 ${ }^{11)}$ 。地域の都市 化の状況と小学校区毎の児童数等の地域条件及び施設の整備状況を 一体的に把握するため、分析単位は小学校区 (2010 年時点) とした。

\section{4. 地域条件指標を用いた校区の地域類型}

学童保育施設の小学校区における設置形態は、校区の地域条件に 規定される側面が大きい。そこで本章では先ず学童保育実施校区の 立地条件、校区面積. 児童数の多様性を考慮し、数量化理論而類及び クラスター分析により 2010 年時点における小学校区を単位とした 地域の類型化を行う。

\section{1 数量化 III 類分析}

校区の地域条件として以下に示す 5 指標を設定した。

（1）農業地域類型：農林水産省による農業地域類型注 9) は、1950 年 時点の自治体区分毎に都市的, 平地, 中間, 山間農業地域に区別さ れているため、大半の小学校区は 1 類型に該当した。一部 1 校区

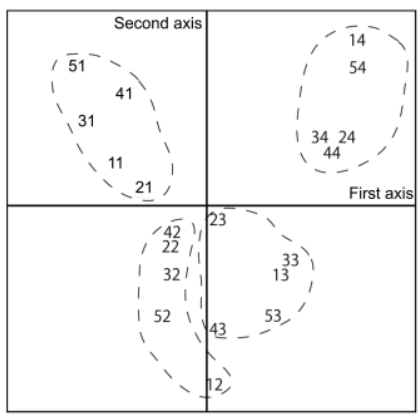

(a) Category score of axis 1,2

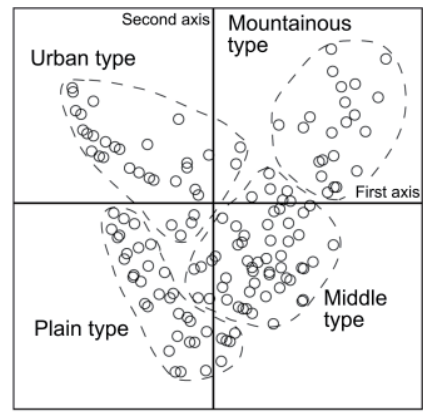

(b) Sample score of axis 1,2 Fig.1 Result of Quantification theory analysis

\begin{tabular}{|c|c|c|c|c|c|}
\hline Pattern & \begin{tabular}{|c|} 
First axis \\
第1軸
\end{tabular} & $\begin{array}{l}\text { Second axis } \\
\text { 第2軸 }\end{array}$ & \multicolumn{3}{|c|}{ Dendrogram/デンドログラム } \\
\hline Urban type & -1.00 & 0.53 & 0 & 20 & 30 \\
\hline Plain type & -0.50 & -0.26 & & & \\
\hline Middle type & 0.35 & -0.56 & & & \\
\hline Mountainous type & 1.14 & 0.60 & & & \\
\hline
\end{tabular}

Fig.2 Result of cluster analysis by two category scores

内に複数の農業地域類型が見られたが、この場合は面積割合の高 い農業地域類型を適用した。

（2）児童維持率 $(\%):(=2010$ 年児童数/1995 年児童数 $\times 100)$ 学童保育が览童福祉法に位置付けられた 1997 年に近い 1995 年時 点の児童数を 100 とした場合の 2010 年の児童数の割合である。

（3）対象児童数 (人)：(=2010 年校区児童数 $\times$ 共働き世帯率 $\times 0.5)$ 学童保育必要児童数を算定するため、校区児童数に共働き世帯率 （6-12 歳児童をもつ共衝き世帯数/6-12 歳児童をもつ世帯数）を乗 じる。共働き世帯率は国勢調査より旧市町村単位に算出し、1 市 町村内の校区は同一比率を与えた。これに一律 0.5 を乗じ $1 \sim 3$ 学年の対象児童数を求めた。

（4）校区面積 $\left(\mathrm{km}^{2}\right)$ : 校区面積は施設への児童の通所及び保護者の送 迎利便性に関連し、都市部と農村部では面積の差が大きいため指 標に設定する。

（5）児童密度 $\left(人 / \mathrm{km}^{2}\right) ：(=2010$ 年児童数/校区面積) 都市部と農村部の児童密度には差があるため指標に設定する。 表 3 にカテゴリー一覧を示す。度数分布をもとに地域条件指標を 各々 4 カテゴリーに区分したが、この内農業地域類型は全国同一基 準により 4 区分されており、山口県の類型別校区数には差がある。 数量化林類分析によりこの 5 指標 4 群の計 20 カテゴリーのスコアを 算定した。カテゴリースコア分布を図 1 (a) に示す。第 1 軸は十側に 山間的特徵を示すカテゴリー、一側に都市的特徵を示すカテゴリー が布置しており、第 1 軸は校区の都市・山間地域特性を示寸軸と解釈 される。第 2 軸は十側に各カテゴリーの最大最小值が布置し、一側 に中位值が布置することから、校区数の多い平地・中間地域の特徵を 示寸軸と解釈される。

\section{2 クラスター分析による地域類型}

第 1, 2 軸のサンプルスコアを用いたクラスター分析 (ward 法)によ る校区の類型化を行い、「都市型」,「平地型」,「中間型」,「山間型」の 4 類型に区分した。サンプルスコア分布を図 1(b)、デンドログラムを 図 2 に示す。また各類型の特徴を検討するため、地域条件指標と基 
Table4 Local conditions of school attendance unit types

\begin{tabular}{|c|c|c|c|c|c|c|c|c|c|}
\hline \multirow[b]{2}{*}{ Pattern } & \multirow[b]{2}{*}{ 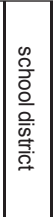 } & \multicolumn{4}{|c|}{ Average of regional condition } & \multicolumn{4}{|c|}{ Average of basic data } \\
\hline & & $\begin{array}{c}\text { Pupil } \\
\text { mainte } \\
\text {-nance } \\
\text { rate } \\
(\%)\end{array}$ & $\begin{array}{c}\text { Number } \\
\text { of target } \\
\text { pupils } \\
\text { (people) }\end{array}$ & $\begin{array}{c}\text { school } \\
\text { district } \\
\text { area } \\
\left(\mathrm{km}^{2}\right)\end{array}$ & \begin{tabular}{|c|} 
Pupil \\
density \\
(people/ \\
$\mathrm{km}^{2}$ )
\end{tabular} & \begin{tabular}{|c} 
Pupil \\
number \\
in \\
1995 \\
(people)
\end{tabular} & \begin{tabular}{|c} 
Pupil \\
number \\
in \\
2010 \\
(people)
\end{tabular} & \begin{tabular}{|c|} 
Rate of \\
dual \\
income \\
househo \\
-lds (\%) \\
共偅き \\
率 \\
\end{tabular} & $\begin{array}{c}\text { Register } \\
\text {-ed } \\
\text { pupils } \\
\text { (people) } \\
\text { 登録 } \\
\text { 児童数 }\end{array}$ \\
\hline $\begin{array}{l}\text { rba } \\
\text { pe }\end{array}$ & 78 & 82.4 & 158 & 4.8 & 142.7 & 649 & 527 & 59.7 & 68 \\
\hline $\begin{array}{l}\text { Plain } \\
\text { type }\end{array}$ & 68 & 83.2 & 103 & 11.9 & 33.4 & 399 & 325 & 63.1 & 45 \\
\hline $\begin{array}{l}\text { Middle } \\
\text { ype }\end{array}$ & 111 & 65.8 & 34 & 18.1 & 7.0 & 152 & 97 & 70.1 & 15 \\
\hline $\begin{array}{l}\text { Mount } \\
\text { ous ty }\end{array}$ & 64 & 41.4 & 14 & 42.0 & 1.0 & 85 & 35 & 75.3 & 7 \\
\hline
\end{tabular}

Table5 Facilities management types in each school attendance unit in Yamaguchi prefecture

\begin{tabular}{|c|c|c|c|c|c|c|c|}
\hline \multicolumn{2}{|c|}{$\begin{array}{c}\text { Types of } \\
\text { School district } \\
\text { 校区分類 }\end{array}$} & \multicolumn{2}{|c|}{$\begin{array}{c}\text { School } \\
\text { districts } \\
\text { 校区 }\end{array}$} & $\begin{array}{c}\text { Compo- } \\
\text { sition } \\
\text { ratio (\%) }\end{array}$ & \multicolumn{2}{|c|}{$\begin{array}{c}\text { Facility number } \\
\text { S facility O facility }\end{array}$} & Outline/ 概要 \\
\hline & S1 & & 119 & 37.1 & 119 & 0 & Districts where has S facility/S施設を開設 \\
\hline & S2 & 147 & 28 & 8.7 & 56 & 0 & Districts where has $2 \mathrm{~S}$ facilities/S施設を2開設 \\
\hline \multirow{4}{*}{$\begin{array}{l}S+O \\
\text { type }\end{array}$} & $S+0$ & \multirow{4}{*}{25} & 19 & 5.9 & 19 & 19 & $\begin{array}{l}\text { Districts where has } \mathrm{S} \text { facility and } \mathrm{O} \text { facility } \\
\text { Si施設を1、O施設を1開設 }\end{array}$ \\
\hline & $\mathrm{S} 2+\mathrm{O}$ & & 2 & 0.6 & 4 & 2 & $\begin{array}{l}\text { Districts where has } 2 \mathrm{~S} \text { facilities and } \mathrm{O} \text { facility } \\
\text { S施設を2施設、O施設を1施設を開設 } \\
\end{array}$ \\
\hline & $\mathrm{S}+\mathrm{O} 2$ & & 2 & 0.6 & 2 & 4 & $\begin{array}{l}\text { Districts where has } S \text { facility and } 20 \text { facilities } \\
\text { S施設を1、O施設を2を開設している校区 }\end{array}$ \\
\hline & $\mathrm{S} 2+\mathrm{O} 2$ & & 2 & 0.6 & 4 & & $\begin{array}{l}\text { Districts where has } 2 \mathrm{~S} \text { facilities and } 20 \text { facilities } \\
\text { S施設を2、誨設を2開設しているる校区 } \\
\end{array}$ \\
\hline & 01 & \multirow{3}{*}{78} & 64 & 19.9 & 0 & 64 & Districts where has O facility/O施設を開設 \\
\hline \multirow[t]{2}{*}{ O type } & $\mathrm{O} 2$ & & 12 & 3.7 & 0 & 24 & Districts where has 20 facilities/O施設を2開設 \\
\hline & 03 & & 2 & 0.6 & 0 & 6 & Districts where has 30 facilities/O施設を3開設 \\
\hline \multicolumn{2}{|c|}{$\mathrm{N}$ type } & \multicolumn{2}{|c|}{71} & 22.1 & 0 & 0 & Districts where has no facilities/学童保育が未開設 \\
\hline \multicolumn{2}{|c|}{ Total } & \multicolumn{2}{|c|}{321} & 100 & 204 & 123 & \\
\hline
\end{tabular}

on the site)/学校敷地内(空き教室、小学校敷地内専用施設)

facility: Facilities except elementary schools (Community center, children's center, nursery school,dedicated facilities, etc. $/$ 小学校以外の施設(公民館、児童館、保育園、専用施設等)

Note) S2, $\mathrm{O} 3$ and Four type of $\mathrm{S} 2$ and $\mathrm{S}+\mathrm{O}$ type is established by dividing the classrooms. クラスを分割する等して複数施設開設

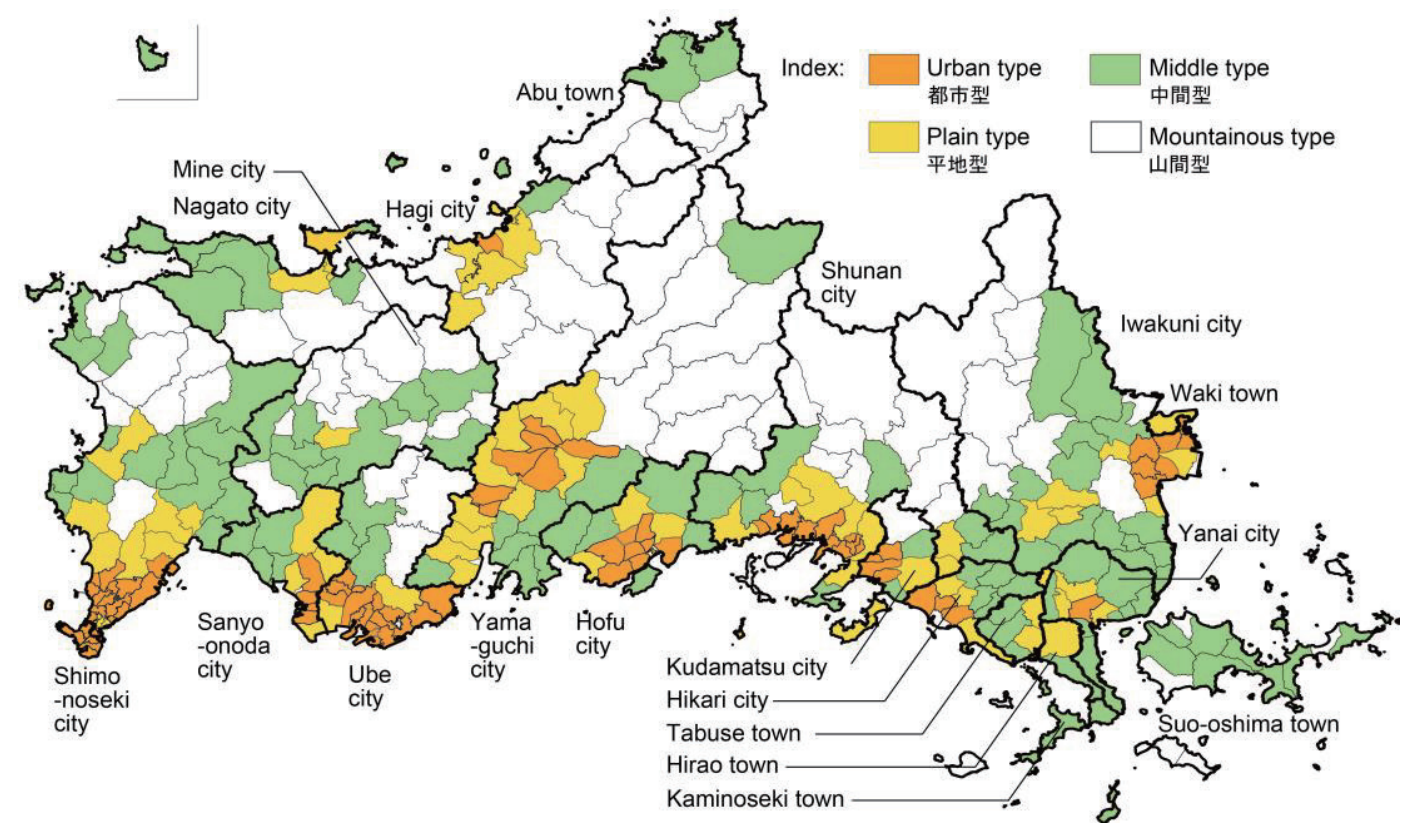

Fig.3 Map of classified school attendance unit types

礎データを表 4 に整理した。

「都市型」は 78 校区あり、平均校区面積が $4.8 \mathrm{~km}^{2}$ と狭くかつ平均 児童密度が 142.7 人 $/ \mathrm{km}^{2}$ と高い。1995 年と 2010 年の 1 校当たり平 均児童数は各々 649,527 人で、児童維持率 (2010 年児童数/1995 年児 童数) は $82.4 \%$ と高く、小学校の対象児童数 $(158$ 人) - 登録児童数 $(68$ 人)ともに最も多く、人口 20 万人以下の地方の小都市群ではあるが、 児童数の減少が少ないのが特徵である。「平地型」は68 校区あり、平 均校区面積は $11.9 \mathrm{~km}^{2}$ で都市型」と比較すると 2 倍以上広く、逆に 児童密度は 33.4 人 $/ \mathrm{km}^{2}$ と低いが、1 校当たり平均児童数は 399 (1995 年)、325 人 (2010 年) の中規模校区で、児童維持率は $83.2 \%$ と都市型 同様児童数の減少は少ない。対象児童数 $(103$ 人) ·登録児童数 $(45$ 人) も「都市型」に次いで多い。

「中間型」は校区数が 111 と多く、山口県における主要な小学校区 の型である。校区面積は $18.1 \mathrm{~km}^{2}$ と「平地型」より広く、巟童密度は 7.0 人 $/ \mathrm{km}^{2}$ と「平地型」に比べ $1 / 5$ 以下と低いのが特徵で、 1 校当たり 平均児童数は 152 人 (1995 年)、97 人 (2010 年) と少なく、览童維持
率は $65.8 \%$ と児童減少数が顕著な点が指摘される。この結果、対象 児童数 $(34$ 人) ·登録児童数 $(15$ 人) ともに平地型の 3 割程度と少なく なり、学校の小規模化が進行した校区である。「山間型」は 64 校区で 「中間型」の 6 割程度の校区数であるが、過疎地域のため校区面積は $42.0 \mathrm{~km}^{2}$ で「中間型」の 2 倍以上広く、逆に児童密度は 1.0 人 $/ \mathrm{km}^{2}$ と 低い。1 校当たり平均児童数は 85 人 (1995 年), 35 人 (2010 年)と校区 乱童数が少ない小規模校区で、かつ児童維持率は $41.4 \%$ と児童数の 減少が著しいため、対象児童数 $(14$ 人) - 登録児童数 $(7$ 人) ともに「中 間型」の $1 / 2$ 以下と少なく、学童保育の成立或いは存続が困難な状況 の校区が多い事を示す。

\section{3 地域類型の分布形態}

校区毎の地域類型分布を図 3 に示す。山口県は瀬戸内海沿岸を主 とする都市分散型の地域構造を有す県で、瀬戸内海沿岸に位置する 県内主要都市の下関・山陽小野田・宇部・防府 $\cdot$ 周南 $\cdot$ 光 $\cdot$ 下松・柳井·岩 国、県央の盆地に位置する山口市、日本海沿岸に位置する萩市の中 心市街地や周辺市街地に位置する校区が都市型に属している。一方 


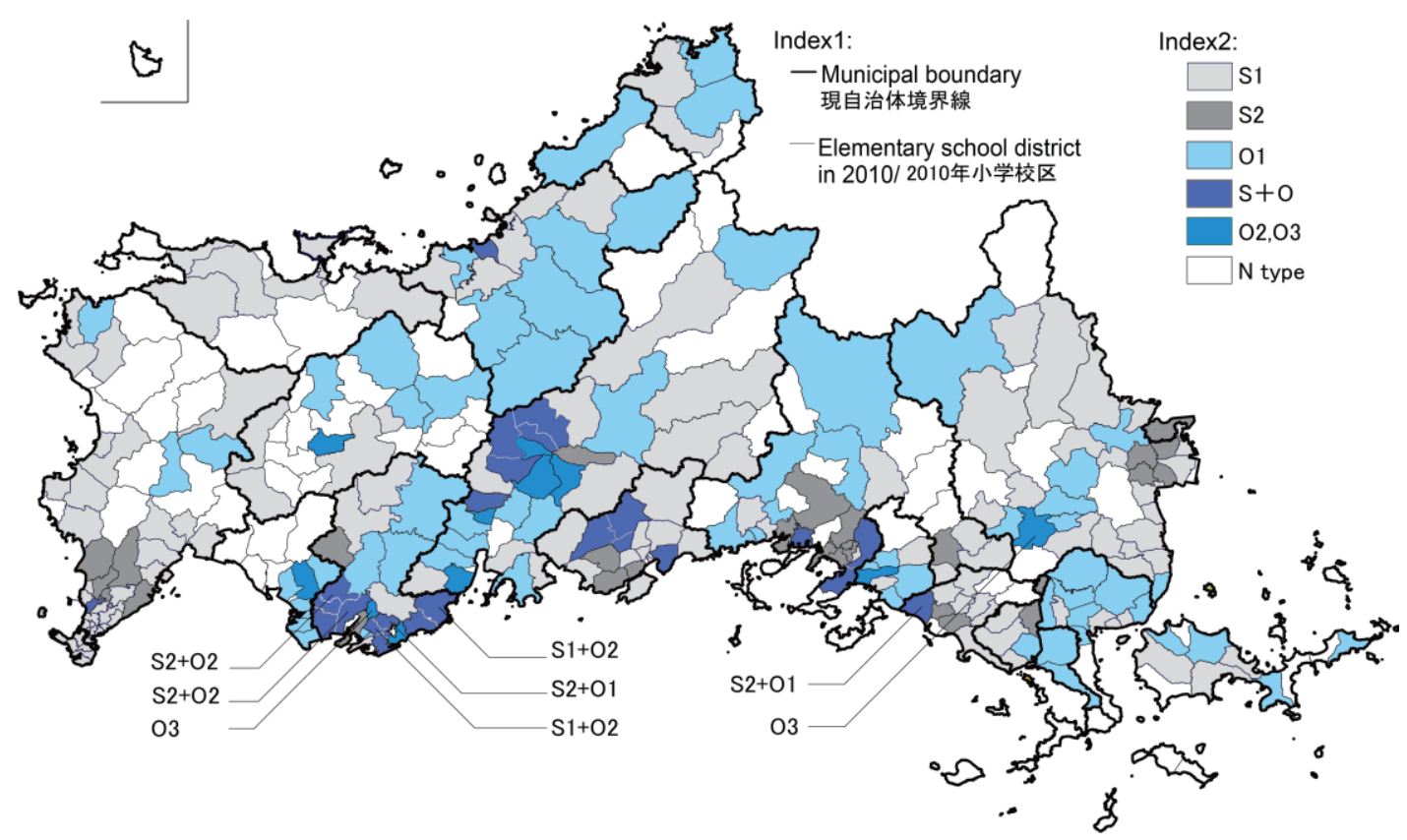

Fig.4 School area map of facilities management types in Yamaguchi prefecture

日本海沿岸の長門市や内陸部の美祢市の人口規模の小さい都市地域 では、市街地においても都市型校区は見られない。「平地型」は主に 「都市型」隣接校区或いはその周辺部に位置する校区で、平成の市町 村合併以前の旧市に該当する地域の校区が大半であり、全体的には 「中間型」は分散都市構造を有す地域特性を反映し、旧下関と宇部市、 旧山口と防府市、旧防府と徳山市 (現周南市)、旧柳井と岩国市等の 都市間に位置する沿岸部の農村地域に位置する校区群と、「平地型」 と「山間型」の中間に位置する農村地域の校区や、長門·美祢市等の市 街地周辺に位置する校区群で構成される。「山間型」は主に県内陸部 の「中間型」よりもさらに山間地域に位置する校区で、中国山地の広 島・島根県境地域では面積の広い校区が多く見られ、旧萩・長門市周 辺地域にも面積の広い校区が多く位置している。このため平均校区 面積は $42.0 \mathrm{~km}^{2}$ と「中間型」 $\left(18.1 \mathrm{~km}^{2}\right)$ の 2 倍以上の広さがあり、校 区数は 64 校区で全体の 2 割であるが面積の割合は高い。

\section{5. 学童保育施設の校区別設置型}

\section{1 校区別設置型の分類}

山口県には休校を除く公立小学校が 321 校(2010) あり、250 校区 で学童保育が実施されていた。学童保育施設は放課後児童クラブと 呼称され、県内に 327 施設 (2010) が開設されていた。学童保育施設 の開設は小学校敷地内が基本となることから、校舎内及び校庭に建 設されたプレハブ等の施設を含む敷地内施設を「S 型」施設、公民 館, 児童館, 保育園や学校敷地外に建設された専用施設等を利用する ものを「O 型」施設に分類した。S 型施設は 204 事例、O 型施設は 123 事例あり、山口県で開設される学童保育施設の内 $37.6 \%$ は小学 校以外の施設が活用されていた。

次にこの基本施設分類をもとに各校区の詳細設置型を設定した。 $\lceil S$ 型」,「S+O 型」,「O 型」,「N型」に分類し、さらに 1 校区内に開設さ れている施設数を加味し、「S 型」は S1, S2、「S+O 型」は S+O, S2+O, $\mathrm{S}+\mathrm{O} 2, \mathrm{~S} 2+\mathrm{O} 2 、 \mathrm{O}$ 型」は校区内施設数に応じ 01 O3 に区分し、N
型を含め合計 10 タイプに細分類した。分類結果を表 5 に示す。学童 保育施設の基本型である学校内に 1 施設開設される「S型」が 147 校 区 $(45.8 \%)$ と最も多いが、山口県では学校以外の 1 施設を利用する $\lceil\mathrm{O}$ 型」が 78 校区 $(24.2 \%)$ と「S 型」に次いで多いのが特徵である。1 校区に 2 施設が開設される設置型は S2 型, S+O 型, O2 型で、最も多 い方式は校舎内に 2 箇所或いは校舎内と校庭に建設された事例を含 むS2 型 $(8.7 \%)$ である。3 施設以上の事例には S2+O, S+O2, S2+O2, O3 型があり、いずれも O 型施設を組み合わせた形態で、校区の児 童数が多くなると小学校以外の施設も活用される傾向が認められる。 一方、学童保育未実施の「N型」が 71 校区 $(22.1 \%)$ あり、自治体にお ける学童保育サービスの地域的不均衡問題注 12$)$ が存在した。

\section{2 校区別設置型の分布形態}

校区別設置型の分布を図 4 に示す。监童数の多い「都市型」校区が 集積する旧市の中心地域を見ると、宇部・山口・防府・周南・下松・光 市等では S2 型,「S+O 型」,O2 型等の複数開設校区が分布するが、下 関·岩国・萩・長門市ではS1 型或いはS2 型校区が多く、「都市型」校 区が少ない柳井・美祢市では S1 型,01 型校区が主で、自治体による 校区範囲の設定方法、校区内览童数や学校外施設を含めた学童保育 施設整備方針の反映と考えられる。市中心市街地周辺部の「平地型」 校区には、S1 型の校区が比較的多く分布するが、同時に学校外施 設の01 型校区もみられ、校区内览童数が「都市型」校区よりも少な $く 、 S 2$ 型,「S+O 型」等の複数開設校区は旧市中心地域に比べ少ない。 児童数が少ない「中間型」校区が大半の農村·島嶼地域では、「平地型」 校区同様 S1,01 型校区が大半を占めるが、下関市の北部や山陽小野 田市等には施設が開設されていない「N 型」校区も多く見られ、その 分布形態には地域的なまとまりは見られない。一方内陸部の山間地 域では、施設未開設の「 $\mathrm{N}$ 型」校区が多く分布するが、「中間型」校区 に多いS1 型に加え、県境地域や旧萩・長門市周辺地域では 01 型の 校区も多く、山口県の山間地域校区の施設形態はこれらの 3 類型に 特化していた事がわかる。 


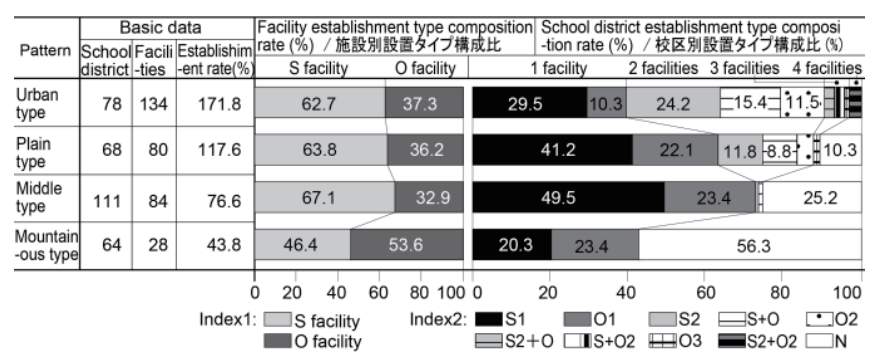

Fig.5 Institution type and rate by school attendance unit types

\section{6. 地域類型と整備水準の関係}

\section{1 地域類型別設置率と設置型}

地域類型別の設置率と設置型を図 5 に示す。「都市型」校区の合計 施設数は $134(/ 78$ 校区) で、平均設置率は $171.8 \%$ と高い。内訳は S 型が 6 割以上と多いが、主要都市市街地の校区においても O 型施設 が 4 割近くを占める。校区別設置型の構成比は、 1 施設のみの校区 は約 4 割で内 1 割は O 型である。 2 施設校区が $51.3 \%$ と割合が高く、 内学校内に 2 施設が開設される S2 型の割合 $(24.4 \%)$ が高いものの、 O 型施設を含む $\mathrm{S}+\mathrm{O}(15.4 \%) 、 \mathrm{O} 2(11.5 \%)$ の割合も高いのが特徵と いえる。3 施設以上の校区 $(9.0 \%)$ は少ないが全て ○ 型施設を含む $(\mathrm{S} 2+\mathrm{O}, \mathrm{S}+\mathrm{O} 2, \mathrm{O} 3, \mathrm{~S} 2+\mathrm{O} 2)$ 。「平地型」校区の合計施設数は 80 (/68 校 区) で、平均設置率は $117.6 \%$ と 1 校区 1 施設が開設され、内訳は「都 市型」と同様である。校区別設置型構成比は、 1 施設のみの校区が 6 割以上で内 2 割以上が O 型である。2 施設校区は $26.5 \%$ と都市型」 と比較すると割合が低いが、S2 型: $11.8 \% 、 S+O$ 型:8.8\%、O2 型:4. 4\% の構成比で、学校以外の施設を含む校区の割合が高い。3 施設以上 の校区は少なく $(1.5 \%)$ 、施設未設置 $(\mathrm{N}$ 型) 校区が 1 割ある。

「中間型」校区の合計施設数は $84(/ 111$ 校区) で、平均設置率は $76.6 \%$ と「平地型」より相当低い。内訳は $67.1 \%$ S 型で最も割合が高 く、設置型の構成比は 1 施設のみの校区が 7 割以上で内 5 割が $\mathrm{S}$ 型 である。2 施設以上の校区は $1.8 \%$ と少なく、一方で N 型が $25 \%$ を占 める。「山間型」校区の合計施設数は 28 (/64 校区) で、設置率は $43.8 \%$ と「中間型」と比較するとさらに低く、他の地域類型と異なり $\mathrm{O}$ 型施 設の割合 $(53.6 \%)$ が S 型施設より高い。設置型の構成比は 1 施設の みの校区が $43.7 \%$ で 23.4\%が O 型である。2 施設以上の校区は皆 無で、N 型校区が $56 \%$ を占め「中間型」と比較しても学童保育未整備 校区の割合が高く、対象児童の絶対数が少なかった点が要因として 指摘される。

このように、山口県の「山間型」校区では施設未設置 $(\mathrm{N}$ 型) 校区が 半数以上を占め、かつ学童保育実施校区の半数以上が O 型施設で、 学校を利用した S 型の施設運営事例が少ないのが特徵といえる。県 内の学童保育未実施自治体へのアンケート調查によれば(表 6)、学 童保育は「放課後児童健全育成事業費補助金」制度により国から $2 / 3$ の補助を受けるが、補助金交付要件 (1 日の来所児童数の月平均が 10 人以上)を満たせないため実施に至れないと回答した事例が 62 校区 (/64) と大半を占め、過疎地域の小規模校ではこの運営補助基準が学 童保育実施の险路となっていた経緯を示している。但し、学童保育 未実施校区のある自治体の中で、児童数が少なく学童保育の実施が 困難な小規模校に対し、児童全員を対象とした「放課後子ども教室」 を実施し対応していた自治体 (NA 市: 放課後子ども教室 5 校区/12) が あり、運営組織や人材確保等の課題はあるものの、過疎地域におい
Table6 Reason for no facility (in all 64 school attendance units) in Yamaguchi prefecture

1) The government subsidizes $2 / 3$ of the project through the After-School Child Health Promotion Project Subsidy, but the project cannot be implemented because it does not meet the subsidy requirements (monthly average of 10 or more children per day) (62 school districts).

「放課後児童健全育成事業補助金」により国から2/3の補助を受けて実施している 『放課後児童健全育成事業補助金」により国から $2 / 3$ の補助を受けて実施している
が、補助金の交付要件(1 日の来所持同数の月平均が 10 人以 )を満たせないた か、補助金の交付要化

An opinion survey will be conducted among parents of new students, and if more than 10 parents are expected to continue using the school, the school will be opened.I 保護者の要望が強まった校区では新入生保護者に対し意識調查を 実施し、10 人以上の継続的な利用が予測された際は開設

In small schools, after-school children's classes are provided, so the facility is not established. (5 facilities in Nagato city)/ 児童数が少ない小規模校では放課後 子ども教室を実施し対応しているため、学童保育は未実地

Table7 Reason for selection of O type (in 16 old mountain type municipal corporations) in Yamaguchi prefecture

1) There was no vacant classroom, and facilities were sought and opened. (10 facilities)/ 空き教室が存在せず、開設できる施設を探して実施

2) Since the operation was not accepted within the elementary school from the beginning, it was opened at the location of the Social Welfare Council or the Board of Education, which commissioned the operation. (3 facilities) 開設当初から小学校内での塞施を受け入れていなかったため、運営を委託した社協 や教育委員会の所在地で実施

3) It was opened because there is a property with good conditions nearby and advantages such as security equipment. (6 facility)

学校隣接地に条件の良い物件があり、防犯設備等のメリットがあるため開設

Many municipalities intend to relocate the classrooms as soon as they become available./ 多くの自治体で今後の開設は小学校内とし、空き教室ができ次第移設

て放課後学童保育を必要とする共働き世帯に対する現実的かつ的確 な対応として評価される。

また「山間型」校区の○型施設設置自治体への聞取り調查(16旧自 治体)によれば(表 7)、複数回答として、小学校に空き教室がなく開 設出来る他の施設を探し実施に至った事例 (10 校区)、学童保育実施 当初は小学校で受入れておらず、運営を委託する社会福祉協議会や 教育委員会の所在地で開始した事例 (3 校区)、学校隣接地に利用可 能な建物 (元保育園, 坚童館等)があり、これらの施設を活用し学童 保育を開設した事例 (6 校区) がある。過疎地域の小学校の場合、空 き教室の活用は現実的選択肢としてあり得るものの、小規模校では 学校運営のための人材が少ないため、放課後の学童保育に対応可能 な体制を組むことが困難な学校も多く、小学校以外の外部組織によ る○型施設の運営が行われていたと考えられる。過疎地域の小学校 の空き教室の有効利用に関しては、学童保育の運営組織や運営費用 確保を含め、自治体による活用方策の検討が必要といえる。

以上、地域類型と施設設置率及び校区内の施設設置形態の間には 明瞭な関係が認められ、「都市型」及び「平地型」校区では児童数に対 応して学校以外の施設を含めた複数施設の整備が行われていたの に対し、「中間型」校区の地域では約 $1 / 4$ の校区で施設が未整備で、 さらに「山間型」の地域では児童数が少ないため半数以上が学童保 育未整備校区で、整備校区でも学校以外の施設が半数以上を占める 状況にあり、地域による整備率の格差が大きい点が指摘される。こ の中で各地域類型に共通して学校以外の施設が学童保育施設の水 準向上に寄与していた点は注目すべきで、学校のみでなく地域の既 存施設の有効活用による学童保育の更なる充実が展望される。

\section{2 設置率と対象児童数・登録児童数の関係}

対象児童数の内、学童保育利用児童として登録されていた児童数 (2010 年 5 月時点)の割合を示寸利用率 $(=$ 登録巟童数/対象児童数 $\times 100)$ を算定した。対象児童数と登録児童数の関係と利用率算定結 を図 6 に示す。利用率は「都市型」 $(44.6 \%)$ 、「平地型」 $(42.2 \%)$ 、「中 


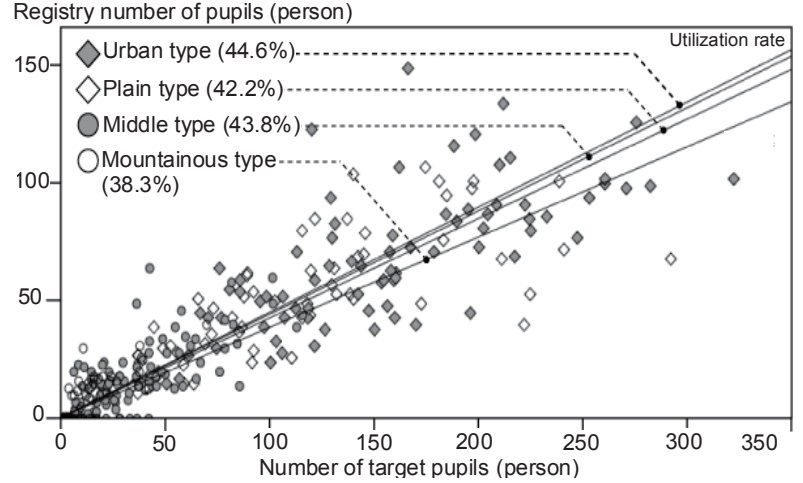

Fig.6 Candidate number of pupils and utilization ratio

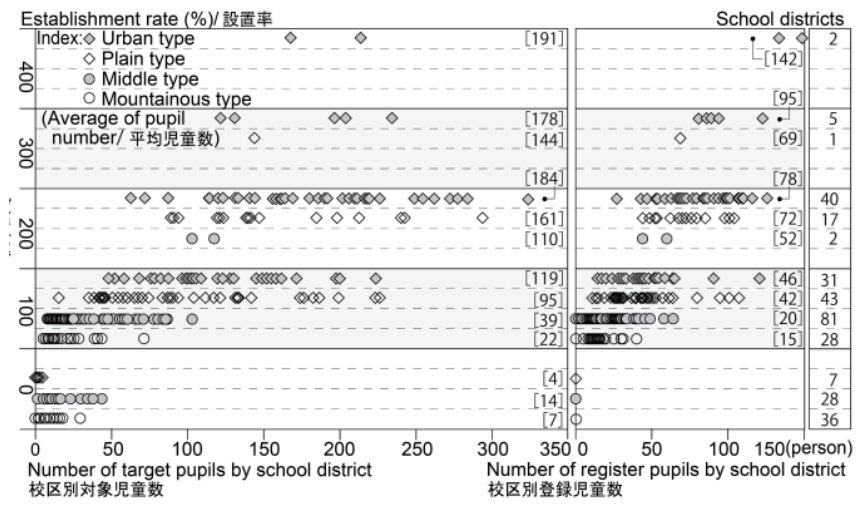

Fig.7 Relation among candidate, registered pupils and facilities institution ratio

間型」(43.8\%)で、全体として対象児童数の約 4 割強が来所していた ことになる。これに対し共働き世帯率の高い山間型校区 (75.3\%)で 利用率 $(38.3 \%)$ が低い結果であるが、これは山間地域の農山村では 3 世代同居世帯の割合が都市部よりも相対的に高く注 ${ }^{13)}$ 、祖父母等に よる放課後の児童の世話が可能な世帯が一定の割合を占める点も 影響していたと推察される。

次に設置率と対象児童数・登録児童数の関係について検討するた め、設置率別に各地域類型の対象児童数と登録児童数を図 7 に整理 した。未設置校区では各類型とも対象児童数は平均 15 人未満と少な く、50 人を上回る校区は見られない。設置率 $100 \%$ ( 1 校区 1 施設)の 校区の平均対象児童数は「都市型」の 119 人から「山間型」の 22 人まで 順次減少しその差が大きく、登録児童数も同様の傾向が認められる が、「都市型」でも平均 46 人で 60 人を上回る校区は少ない。設置率 $200 \%$ (1 校区 2 施設)の校区の平均対象児童数は「都市型」で 184 人、 「平地型」で 161 人と大差なく、登録児童数は各々 78,72 人と推奨基 準を上回るため、1 校区に 2 施設が設置されたものと推察される。 設置率 300\%(1 校区 3 施設) 以上の「都市型」の 7 校区では、登録児童 数が 95 ～142 人とさらに多く、複数施設開設による大規模化の回避 措置が講じられた事を示す。

\section{3 施設の登録児童数}

地域類型と施設利用登録児童数の関係を検討するため、校区類型 別に施設毎の登録児童数(2010 年)を図 8 にまとめた。「都市型」校区 の平均登録児童数は 68 人/施設と多いが、複数の施設が開設されて いた校区が多いため、70 人以上の施設は $5.8 \%$ と少なく、大半は推奨
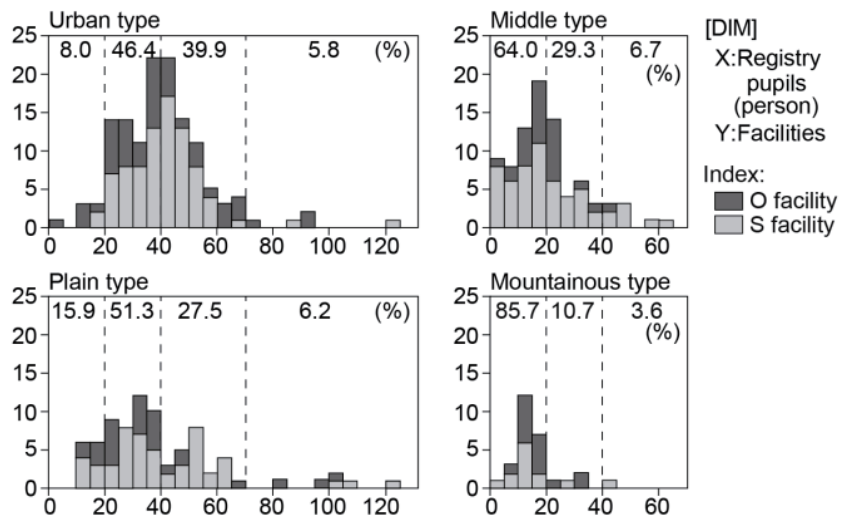

Fig. 8 Facilities number by registry pupil's rank

基準の 70 人以下に収まっていた。但し、40〜70人の範囲の施設が 4 割を占めるため 40 人以下の施設は $54.4 \%$ 、半数近くの施設で新設 置基準の「40人/施設以下」は満たされていない。一方で 30 人以下の 施設も $28 \%$ あ、览童数の多い「都市型」校区においても小規模な運 営が行われていた施設も存在する。「平地型」校区の平均登録児童数 は 45 人で、「都市型」同様 70 人以上の施設は $6.2 \%$ と少なく、大半は 推奨基準の 70 人以下であるが、 $40 \sim 70$ 人の範囲の施設が $27.5 \%$ る ため、新設置基準を満たすには施設の拡充が必要な事を示す。40人 以下の施設は全体の $66.3 \%$ にび、かつ 20 人以下の小規模施設が $16 \%$ を占め、これらの施設では従来通りの施設運営が可能である。

「中間型」校区の平均登録児童数は 15 人と少ないため、40人以上 の施設は $6.7 \%$ と少なく、20 人以下の小規模施設が $64 \%$ 占めること から、小学校の標準的教室面積 $\left(63 \mathrm{~m}^{2}\right)$ の空き教室の場合、全国学童 保育連絡協議会の提言注 ${ }^{14}$ ) (生活室・プレイルーム面積 : $3.96 \mathrm{~m}^{2} / 人$ 以上) を満足する 施設も多いものと推定される。同様に「山間型」も 1 施設 (41 人) を除き全て 40 人以下で、20 人以下の小規模施設が $86 \%$ を占め、施設規模の面では 2010 年時点で既に新設置基準を満たして いる。

このように、児童福祉法改定による施設規模の設置基準化により、 「都市型」及び「平地型」校区では、定員 40 人を上回る施設での基準を 満たすための施設拡充が必須となるため、小学校の校舎内やグラン ドを利用した増設に加え、学校以外の既存施設を活用した新設・増設 も併せて促進する必要がある。一方、「中間型」及び「山間型」校区の 施設では利用定員と施設面積は 2010 年時点でも適正水準にあると 判断され、学童保育施設未整備校区の解消が課題といえる。

\section{7. 結論}

本論では人口減少が進行する山口県を対象に、小学校区を単位と した地域類型をもとに、2010 年時点の学童保育施設の設置形態の特 徵を整理すると共に整備水準の評価を行い、以下の知見を得た。

1）立地条件と児童数等を指標とした校区特性分析をもとに、校区 面積が狭く児童数が多く児童密度が高い「都市型」校区、校区面積 が「都市型」の 2 倍以上で児童密度は低いが、児童数を維持する中 規模校が多い「平地型」校区、校区面積が「平地型」より広く児童の 減少が顕著で、小規模化が進む「中間型」校区及び過疎地域で児童 密度が低く、校区児童数が少ない「山間型」校区に分類した。

2）学童保育施設は小学校内設置が基本で、設置形態は学校設置型 
(S 型) 校区が $45.8 \%$ を占めるが、学校十学校外施設型 (S+O 型) 校区 と学校外施設型 $(\mathrm{O}$ 型) 校区も各々 7.8, 24. 2\%あり、学校外施設を有 寸校区が全体の 4 割近く $(37.1 \%)$ に及び、学校外施設を活用した学 童保育の取組みが全体的な整備水準向上に寄与していた。

3）览童数の多い都市地域の「都市型」校区の平均施設設置率は $172 \%$ と高く、 1 校 1 施設校区 (S,O 型) は 4 割未満で、 1 校 2 施設以上の 校区の方が多く、S2 型校区 $(24.2 \%)$ に加え $\mathrm{S}+\mathrm{O}$ 型校区 $(15.4 \%)$ と O2 型校区 $(11.5 \%)$ も多いのが特徵で、大規模校区では学校外施設 の果たす役割が大きかった事を示す。また「都市型」校区の周辺に 位置する「平地型」校区の平均施設設置率は $118 \%$ で、 1 校 1 施設校 区 (S,O 型) が各々 $41.2,22.1 \%$ と、「都市型」校区に比べその割合が 高い。このように 1 校区 1 施設配置を基本とし大半の校区で学童 保育が実施されていたが、一方で施設未設置 (N 型) 校区が 1 割存 在した。

4）中山間地域の「中間型」校区の平均設置率は $76.6 \%$ で、 1 校 1 施設 校区 (S,O 型) が各々 $49.5,23.4 \%$ と、「平地型」校区に比べその割合が さらに高く、標準的施設配置のS1 型校区が半数を占めていた。但 し $1 / 4$ の校区で施設が設置されていない。さらに児童数の少ない中 山間地域の「山間型」校区では、半数以上が施設未整備校区 $(\mathrm{N}$ 型) で、施設設置校区では O1 型校区 (23.4\%) と S1 型校区 $(20.3 \%)$ のみ で、他の校区類型に比べ 01 型校区の割合が高いのが特徽で、その 他の設置形態は見られず N, 01, S1 型に特化しており、中でも施設 未整備校区が多いため地域格差が大きかった点が指摘される。

5）都市地域の「都市・平地型」校区の施設登録児童数は大半が推奨基 準の 70 人を下回るが、新設置基準の 40 人を超過する施設が $3 \sim 4$ 割程度存在し、学校内の施設増設に加え学校外施設の新増設の促進 による早急な拡充が課題である。これに対し中山間地域に位置する 「中間・山間型」校区の登録児童数は大半が 40 人を下回り、かつ 20 人以下の小規模施設が $6 \sim 8$ 割以上を占め、適正規模基準は満足す る水準にあるが、施設未整備校区の解消が課題である。

以上、学童保育施設の設置率が全国平均水準にある山口県の場合、 都市地域の校区では 2010 年時点で大半の施設で 70 人規模を下回る が、新設置基準の 40 人規模を満たさない施設も多いため、こうした 校区では施設拡充による適正規模への誘導が主要な政策課題となる。 空き教室を始めとする学校内施設の充実と共に、登録児童数の多い 校区で実施されている学校以外の既存施設を活用した施設整備を併 せて促進することが、現実的かつ有効な方法として位置付けられよ う。特に都市地域では児童数の減少は緩やかで、かつ共働き世帯の 増加が今後も見込まれることから、学校内と学校外施設の併用によ る施設拡充施策が地方都市においても益々重要になると考えられる。 一方児童数減少が今後も進行寸ると予測される中山間地域の校区 では、小学校以外の施設を含め 2010 年時点で大半の施設で設置基準 の 40 人規模を満足していたため、学童保育実施校区では新たな施設 整備の必要性は低い。一方で児童数の少ない未整備校区を多く抱え ており、こうした地域では都市地域よりも共㗢き世帯率が高い状況 を鑑みると、需要量そのものは少ないとはいえ学童保育を必要とす る世帯に対応するための施設設置の方法、運営方式に関する早急な 検討が必要と考えられる。具体的には、児童数の少ない小規模校で 運営補助金交付要件に満たず学童保育が実施出来ない場合には、児 童全員を対象とする「放課後子ども教室」を実施する方法も有効な方
策として位置付けられる。この他にも校区の住民や各種の組織を主 体とする、公的制度の枠を超えた地域の状況に柔軟に対応可能な支 援方策の検討と取組みが重要と考える。

本論では、旧自治体を単位とした中国地方 5 県の学童保育施設の 広域的整備状況報告 ${ }^{3)}$ に続き、県単位の詳細分析を目的に、山口県 を対象に小学校区を単位とした地域類型と整備タイプの関係を整理 した。複数の小学校区を有す自治体の地域類型が細区分されるため、 方法論的には特に校区数の多い旧市地域での地域類型と整備タイプ の精緻化が可能となる特徴を有す。この結果、旧自治体を単位とし た地域類型の中国地方 5 県の場合、小学校内設置タイプ（S1 型）が 都市型から山間型地域にかけてその割合が減少したのに対し、小学 校区を単位とした地域類型の山口県の場合には、S1 型の割合が都市 型から中間型地域にかけて増加する結果となった。これは地域類型 の細区分により都市型が減少し中間型が増加したことにより、中間 型地域に多いS1 型校区の割合が高くなったためである。このように、 小学校区を単位とした最小地域類型の設定により、地域類型と整備 タイプの関係をより厳密に把握することができたものと考える。

従って、学童保育施設の県単位の整備状況把握の方法論としては、 小学校区を単位とした各種の関連情報を収集整理することにより、 時系列分析を含め地域的比較分析が可能となることから、学童保育 施設のみでなく地域施設研究の有効な方法論として位置付けられる。

尚、本論では人口・児童数減少が進行する地方県を対象としたが、 大都市圏や地方中枢・中核都市圏を含めた施設整備状況と地域毎の 計画課題の比較検討に関しては今後の課題としたい。

\section{謝辞}

本論は共同研究者の草野啓太氏 ( (株) 内藤建築設計事務所) の修士 論文を再編加筆したものである。末尾ながら記して謝意を表します。

\section{注}

注 1）全国学童保育連絡協議会編, 学童保育情報 2014-2015, 2014. 10 参照 注2）厚生労働省雇用均等・览童家庭局長より「放課後児童クラブガイドライ ンについて」というタイトルで自治体首長宛に平成19年10月に出された通 知である。このガイドラインにより、対象児童、規模、設備などに関し14 項目の基準が示されており、対象児童については「小学校 1 年」、規模に ついては「40人程度までが望ましく、最大 70 人まで」と記載されている。

注3）子ども・子育て関連3法の成立に伴い2014 年6月に児童福祉法が一部改 正され、学童保育施設の設置基準が定められ、規模は「支援の単位を構成 する児童の数はお打む放 40 人以下」、対象児童は「小学校 $1 \sim 6$ 年」、施設面 積は「1人当たり施設面積を $1.65 \mathrm{~m}^{2}$ 以上」等が規定され、ガイドライン推奨 基準よりも高い整備基準を示している。

注 4）独立行政法人国民生活センター: 学童保育サービスの環境整備に関す る調查研究-都道府県の取り組みに大きな格差-, 2010.3 参照

注 5）中国地方 5 県の旧自治体別に以下の資料を収集した。 (1)放課後児童クラブ一覧 (2012 年)、(2)2000 年市町村区分図、(3)小学校児童 数 (1995・2010 年) 、(4)共働き世帯数 (2000 年)、(5)旧市町村 (1950 年) 別農 業地域類型一覧

注6) 各自治体のHP、健康福祉部、教育委員会、子ども未来課などの学童保育 施設担当部署に問い合わせを行い、クラブ名称、対象校区、開設場所、所 在地の情報を収集した。

注7）国土交通省国土政策局国土数值情報より情報を収集した。

注8）国勢調查 (2010年)をもとに、6歳から12歳児童を持つ世帯数とその内夫 婦共に就労している世帯数を抽出し、共衝き世帯率を算定した。

注9）農林水産省：1950年の自治体区分を基本とする農業地域類型一覧より情 報を収集した。農業地域類型は第1次分類として、都市的地域 (可住地に占 めるDID面積が $5 \%$ 以上で、人口密度 500 人以上又はDID人口 2 万人以上)、平 地農業地域 (耕地率20\%以上かつ林野率50\%未満)、中間農業地域(耕地率 $20 \%$ 
未満で都市的地域及び山間農業地域以外、または耕地率 $20 \%$ 以上で都市的地 域及び平地農業地域以外)、山間農業地域 (林野率 $80 \%$ 以上かつ耕地率 $10 \%$ 未 満)に分類されている。（出典：農林水産省HP/統計情報/農業地域類型につ いて)

注10）該当年度の文部科学省学校基本調査より情報を収集した。

注 11）０型施設を設置する山間地域自治体を聞取り調査対象とした理由は以 下の通りである。（1）都市・平地地域に対し、中間・山間地域では学童保 育施設が未設置の校区が多く、特に児童数の少ない山間地域では学童保育 施設未設置校区が半数以上を占めており、地域施設計画の観点からはこう した未設置校区の解消が大きな課題である事。（2）学童保育施設は小学校 内に設置されるのが基本であるが、中間・山間地域では小学校内設置 (S1 型)に次いで学校外施設 (01 型施設) の割合が高く、特に山間地域では小学 校内設置を上回る設置率を示し、未設置校区解消に向けた有効な取組みと して注目される(Fig. 5 参照)。従って山間地域における学校外施設 (01 型 施設) の設置形態の詳細を把握することは、地域施設計画研究の重要課題 と考えられる。(3) 学童保育施設未設置 (N 型)の校区 (62 校区)に対しては アンケート調査を実施したが、学校外施設 (01 型施設) 設置校区はその数 が少なく、かつ設置経緯を含め個別の事情を把握するには聞取り調査がふ さわしいと判断したため。

注12）自治体における各種の行政サービスは、地域的な不均衡が生じないよ う、住民に対し平等に提供・配分されるのが原則とする考え方である。サー ビスの地域格差問題に関しては、一定地域を対象に施設立地の偏在や格差 を指摘した以下の研究等がある。宮澤仁: 関東地方における介護保険サービ スの地域的偏在と事業者参入の関係, 地理学評論, 76A, pp. 59-80, 2003.2。

注 13） 2000 年の国勢調査結果報告（山口県）によれば、市部（14 市）の 3 世代同居世帯率 $(3$ 世代同居世帯数/核家族世帯数 $)=0.13$ なのに対し、 郡部町村 (42 町村) の 3 世代同居世帯率=0. 21 であり、中山間地域が大 半の郡部町村では 3 世代同居世帯の割合が相対的に高い。尚、本来であれ ば学童保育施設の分析年次の 2010 年時点の 3 世代同居世帯率を比較す心゙ きであるが、平成の市町村合併により、2005 年以降の国勢調査報告では 合併旧町村を含む市単位のデータ及び非合併町のデータのみ公表されてお り、旧市と旧町村を区分した比較が行えないため、平成の市町村合併以前 の 2000 年データをもとに比較している。また 3 世代同居世帯の内学童保育 対象児 (共働き世帯) を放課後家庭内で世話している世帯の実数は国勢調 査結果からは算定不能なため、その割合は都市部・旧郡部共に一定と仮定 すれば、3 世代同居世帯率と学童保育対象児を家庭内で世話する世帯率は 比例することとなる。但し、この点に関しては山間地域における学童保育 需要の実態調査を含め詳細な検討が必要と考える。

注14）全国学童保育連絡協議会の提言（2012.9)では、生活室・プレイルーム の面積を一人当たり $3.96 \mathrm{~m}^{2}$ 以上とする基準が提言されており、この基準を 適用すると、小学校の標準的教室面積 $63 \mathrm{~m}^{2}$ の場合施設定員は16名となる。 中山間地域では 20 人未満の施設が各々 $44 \sim 62 \%$ にぶことから、空き教室 あるいは同等以上の面積を有す学校以外の施設の場合には、2010年時点で も協議会提言基準を満足出来るケースが多いものと推定される。

\section{参考文献}

1) Sugawara, M. et al: Actual Situation and Issues of a School-age Childcare Center in Japan, Journal of Architecture and Planning (Transactions of AIJ), No.675, pp.995-1002, 2012.5 (in Japanese) 菅原麻衣子，林香菜子：全国の学童保育施設における保育環境の実態と整 備課題, 日本建築学会計画系論文集, No. 675, pp, 995-1002, 2012, 5

2) Tsukada, Y. et al: The Status and the Subject for Improvement of After-school Child Care Centers through Local Government's Response to National Policy, AIJ Journal of Technology and Design, No.42, pp.683-688, 2013.6 (in Japanese)

塚田由佳里, 小伊藤亜希子：学童保育所の整備状況と地方自治体の対応か らみた施設整備課題, 日本建築学会技術報告集, No. 42, pp. 683-688, 2013.6

3) Koh, S. et al: Supply Situation of School Child Care Facility by Local Government and Elementary School Unit in Chugoku District, Journal of Architecture and Planning (Transactions of AIJ), No.725, pp.1473-1481, 2016.7 (in Japanese)

孔相権，草野啓太他 3 名：中国地方に捛ける学童保育施設の自治体及び小 学校区単位の整備状況, 日本建築学会計画系論文集, No. 725 , pp. 1473-1481, 2016.7

4) Nakazono, M. et al: Supply Situation of School Child Care Facility by Local Government and Elementary School Unit in Shikoku District,
Journal of Architecture and Planning (Transactions of AIJ), No.752, pp.1855-1863, 2018.10 (in Japanese)

中園眞人, 中村京平他 2 名：四国地方における学童保育施設の自治体及び 小学校区単位の整備状況, 日本建築学会計画系論文集, No. 752, pp. 18551863, 2018. 10

5) Kusano, K. et al: The Status of Development and Management Method of After-school Child Care Center in Ube and Matsue, Proceedings of Annual Research Meeting Chugoku Chapter, Architectural Institute of Japan, No.38, pp.585- 588, 2015.3

草野啓太他 4 名：宇部市・松江市における学童保育施設の整備状況と運営 方式，日本建築学会中国支部研究報告集，No. 38，pp. 585-588，2015.3

6) Miyamoto, F. et al: Activities and Plans in School-Age Child Care Centers, Journal of Architecture and Planning (Transactions of AIJ), No.618, pp.25-31, 2007.8 (in Japanese)

宮本文人, 岩㴊千恵子: 学童保育施設における活動機能と平面構成, 日本 建築学会計画系論文集, No. 618, pp, 25-31, 2007, 8

7) Simizu, H.: Diversity of Children's, Behaviors and Space Composition in an After Childcare Facility, Journal of Architecture and Planning (Transactions of AIJ), No.722, pp.811-819, 2016.4 (in Japanese)

清水肇：学童保育施設における過ごし方の多様性と空間構成，日本建築学 会計画系論文集，No.722，pp. 811-819，2016.4

8) Hosoda, T.: A Study on the Activity Conditions of After School by Types of Service Center in 4 Elementary Schools of Matsue city, Shimane Prefecture, Journal of Architecture and Planning (Transactions of AIJ), No.673, pp.501-509, 2012.3 (in Japanese)

細田智久：島根県松江市 4 小学校における放課後子ども教室の拠点確保別 の活動実態に関する研究, 日本建築学会計画系論文集, No. 673, pp. 501-509, 2012. 3

9) Tsukada, Y. et al: A Study on Facility Improvement and Process of Utilizing Existing Private Buildings for School-age Childcare, Journal of Architecture and Planning (Transactions of AIJ), No.750, pp.14251435, 2018.8 (in Japanese)

塚田由佳里, 小伊藤覀希子：学童保育における民家等活用プロセスと施設 整備の実態, 日本建築学会計画系論文集, No. 750, pp. 1425-1435, 2018.8

10) Nakazono, M. et al: Comparison of Space Utilization Patterns with Pupil's Numbers in Summer Vacation Program at After-school Daycare Center, Journal of Architecture and Planning (Transactions of AIJ), No.753, pp.2109-2117, 2018.11 (in Japanese)

中園眞人他 5 名：学童保育施設における夏休み開催行事「地域塾」の集団 規模と使われ方, 日本建築学会計画系論文集, No. 753, pp. 2109-2117, 2018. 11

11) Nakazono, M. et al: Comparison of Space Utilization Patterns of Afterschool Daycare Center by Pupil's Numbers (24-28 pupils), Journal of Architecture and Planning (Transactions of AIJ), No.767, pp.23-32, 2020.1 (in Japanese)

中園眞人他 4 名：学童保育施設における平日放課後の集団規模 (24-28 人) と使われ方の関係, 日本建築学会計画系論文集, No. 767, pp. 23-32,2020.1

12) Yamazaki, H. et al: A Study of Space Composition Seen from Area of Children's Activities in After-school Daycare Centers, Journal of Architecture and Planning (Transactions of AIJ), No.682, pp.2723-2728, 2012.12 (in Japanese)

山崎陽菜, 定行まり子：学童保育所における子どもの行為に要する面積か ら見た空間構成に関する研究, 日本建築学会計画系論文集, No. 682, pp. 2723-2728, 2012. 12

13) Nakagawa, H. et al: Study on Group Size and Area Scale Based on Grasp of Facility Management at After-school Day-care Center, Journal of Architecture and Planning (Transactions of AIJ), No.695, pp.69-78, 2014.1 (in Japanese)

中川春香，山田あすか：学童保育拠点の運営実態の把握とそれに基づく人 数および面積規模に関する研究, 日本建築学会計画系論文集, No. 695, pp. $69-78,2014.1$ 


\author{
Mahito NAKAZONO ${ }^{* 1}$, Sachiko MISHIMA *2 and Tomohisa HOSODA *3 \\ ${ }^{* 1}$ Emeritus Prof., Yamaguchi Univ., Dr.Eng. \\ *2 Assist. Prof., Institute of Envi. Systems Science, Academic Assembly, Shimane Univ., Dr.Eng. \\ ${ }^{*} 3$ Prof., Institute of Envi. Systems Science, Academic Assembly, Shimane Univ., Dr.Eng.
}

The purpose of this study is to clarify the construction type and supply level of schoolchild care facilities by attendance unit of elementary schools in the Yamaguchi prefecture, and to consider the supply method of schoolchild care facility corresponding to the area's condition. For the analysis, each school attendance unit in 2010 was classified into four types: Urban, Plain, Middle and Mountainous.

The results are as follows.

1) The school establishment-type ( $\mathrm{S}$ type) comprises $45.8 \%$; in addition, the facility type of school and outside school $(\mathrm{S}+\mathrm{O})$ and outside school (O) exist at the rate of $7.8 \%, 24.2 \%$, respectively. School attendance units with facilities outside a school occupy about $40 \%$ of the whole, so the measure of childcare after school, which utilized the facility outside a school, has contributed to improvement in the adjustment level.

2) The average institution rate of "Urban type" with many pupils is as high as $172 \%$. There is a small number of one facility in a school unit (S, O type) that is less than 40\%, and cases of two or more facilities in a school unit that occupy more, in addition to the $\mathrm{S} 2$ type $(24.2 \%)$, the $\mathrm{S}+\mathrm{O}$ and $\mathrm{O} 2$ types, which account for the constant rate. Thus, the role played by outside school facilities is large in large-scale school attendance units. The average institution rate of facility in "Plain type" located around the "Urban type" is $118 \%$ and one facility in a school unit type (S, O type) has a high rate with 41.2 (22.1\%); these rates are higher than the "Urban type". Thus, childcare facility after school has been managed in a large portion of the school units based on one facility in a one-school unit arrangement, but $10 \%$ of uninstalled school units also exist.

3) The average institution rate of the "Middle type" is $76.6 \%$, and the rate of one facility in one-school type (S, O) is 49.5 (23.4\%). Compared with the "Plain type," the rates are high, and the S1 type occupies half of these. On the other hand, more than half of the school units have not prepared the facility in the "Mountainous type" that have few pupils. There is only an $\mathrm{O} 1$ type (23.4\%) and S1 type (20.3\%) in the facility-instituted school units; compared with the other three types, the rate of the $\mathrm{O} 1$ type is high. Other types have not been observed, but are specialized in the N, O1, and S1 types, and in order that many school units' facility is unestablished, the regional gap between types is large.

4) As for the number of facility-registered pupils of the "Urban and Plain types," most have fewer than 70 people at the old recommended standard, but about 30-40\% of the facilities that exceed 40 persons at the new institutional standard exist. The expansion, according to the increase in outside school facilities, was the subject. As for the number of registered pupils of the "Middle and Mountainous type," most have fewer than 40 persons, and 20 or fewer persons' small-scale facilities account for $60-80 \%$ or more; thus the proper size standard is satisfied. However, the dissolution of unprepared school units was the subject of this study.

(2021 年 5 月 6 日原稿受理, 2021 年 8 月 25 日採用決定) 